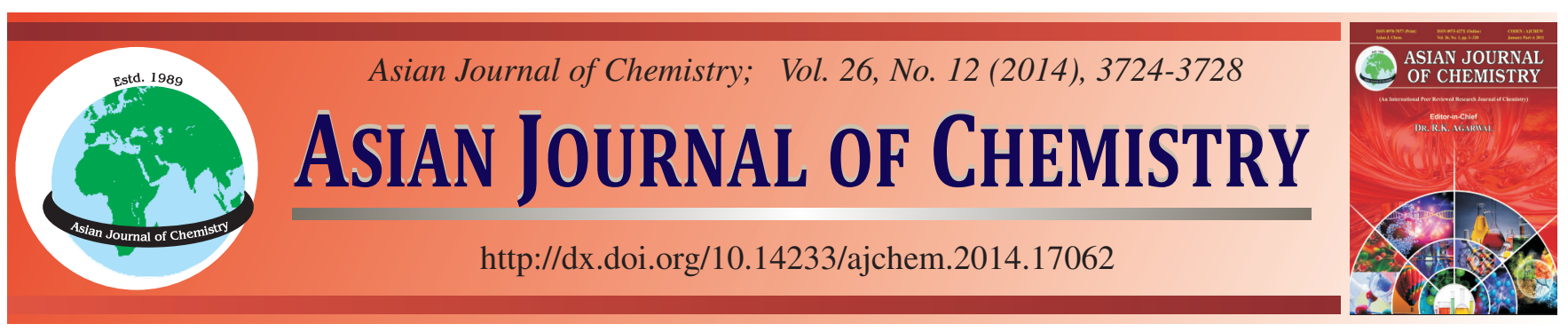

\title{
Extraction and Purification of Lectin by Employing Anionic Surfactant Aerosol-OT Reversed Micellar System and Evaluation of its Antibacterial and Antioxidant Potentials $\dagger$
}

\author{
Senthilkumar Rathnasamy*, S.S. Deepika and B.N. Vedha Hari
}

School of Chemical and Biotechnology, SASTRA University, Thanjavur-613 401, India

*Corresponding author: E-mail: rsenthilkumar@biotech.sastra.edu

\begin{abstract}
Aloe vera is a high potential medicinal plant that contains many active biomolecules like proteins, sugars, amino acids and enzymes. In the present study, lectin from Aloe vera gel and Aloe vera leaf were extracted using non organic method. Sudden denaturation and incompatibleness in the conventional organic extraction method was overcome by biological extraction method. Lectin fractionation was done by ammonium sulphate precipitation and compared with reverse micellar extraction method. The protein content in the crude extracts was estimated to be $2.312 \mathrm{mg} / \mathrm{mL}$ and sample obtained after ammonium sulphate precipitation and reverse micellar extraction was found to be 1.77 and $2.068 \mathrm{mg} / \mathrm{mL}$, respectively. The maximum activity fraction was collected and purified using cationic exchange chromatography on CM sepharose column. Purified fractions from the chromatographic column were collected and confirmed for the presence of lectin by native page analysis. The resulting fractions were assayed for haemagglutination activity using human erythrocytes, in vitro antibacterial activity using agar well diffusion method and in vitro antioxidant activity using reducing power assay. Results revealed that the extraction of lectin from Aloe vera leaf extracts using reverse micellar extraction is an effective method as compared to ammonium sulphate precipitation method and lectin was also found to possess high antioxidant activity with respective to the concentration of lectin and wide spectrum of antibacterial effect. A zone of inhibition against E. coli is (11 mm), of S. typhi (9 mm) is $P$. aeroginosa ( 9 $\mathrm{mm})$, E. aerogenis $(9 \mathrm{~mm})$ and $K$. pneumonia $(5 \mathrm{~mm})$ were observed.
\end{abstract}

Keywords: Lectin, Reverse micellar extraction, Ion exchange chromatography, Haemagglutination, Antioxidant, Antibacterial.

\section{INTRODUCTION}

Aloe barbadensis is botanically equated as Aloe vera belonging to the family Liliaceae (Asphodelaceae). Aloe vera is a perennial, succulent, shrubby, xerophytic, with triangular and fleshy leaves with spiky edges ${ }^{1,2}$. This plant originated from South Africa and now it is distributed all over the world. "Alloeh" is an Arabic word meaning "Shining bitter liquid" and "Vera" is a Latin word meaning "true". The leaves contain three layers, the first layer is the inner gel and it consists of 99 $\%$ water and the remaining $1 \%$ contains amino acids, sterols and vitamins, the second layer is the middle layer and it consists of anthraquinones and glycosides and the third layer is the outer green rind, which consists of carbohydrates and proteins ${ }^{4}$. Aloe vera plants contain more than 200 constituents like hormones, vitamins, enzymes, proteins, anthra-quinones which are used in the treatment of wound healing and as an antibacterial, antiinflammatory and antitumor agent ${ }^{5,6}$.

Lectins are multimeric glycoproteins that bind to the target carbohydrate groups present on the cell surfaces ${ }^{7}$. These are of non-immune origins that are widely distributed in plants and animals. The amino acid sequences, functions, structures and carbohydrate-binding specificities of lectins vary from source to source ${ }^{8}$. Lectin possesses many biological activities such as anti $\mathrm{HIV}^{9}$, mitogenic ${ }^{10,11}$, antiviral ${ }^{12,13}$, antitumor ${ }^{14}$, antifungal ${ }^{15}$, insecticidal ${ }^{16}$ and anticancer activity ${ }^{17}$.

Lectin extraction is usually carried out using ammonium sulphate precipitation method. There are many drawbacks in this method, it includes low extraction rate, high extraction cost, difficulties in purification, scale up problems, high processing time, denaturation and loss of biological activities ${ }^{8}$. These difficulties restrict the usage of lectin in many fields. In order to overcome these difficulties, a new bioseparation methodreverse micellar extraction (RME) technique is used in the present work, which is a liquid-liquid extraction method with reverse micelles for the separation and purification of the biomolecules like proteins and enzymes, without altering their functions ${ }^{18-20}$.

Reverse micelles formed in the processes provides mild operating conditions for the protein recovery from the crude ${ }^{20-22}$. 
By altering the process parameters like $\mathrm{pH}$, salt and surfactant concentration, solvents, it is possible to purify and concentrate the target proteins from the dilute crude extracts in one step ${ }^{23}$. The reverse micelles should be able to solubilize the proteins from the crude in the forward extraction step and the reverse micelles should be capable of releasing the protein, so that the purified protein is obtained from the backward extraction step ${ }^{24-26}$. The surfactants form the reverse micelles (aggregates) when it gets into contact with the non-polar solvents. The surfactant charge should be selected as it is oppositively charged to the charge of the target protein ${ }^{27}$. Advantages of reverse micellar extractions are, easy scale-up process has high resolution capacity, continuous operations, less economic operations and equipment can be designed ${ }^{28}$.

In this study, lectin was extracted by two different methods and was compared for high extraction efficiency and yield. The lectin extracted was studied for its antioxidant and antibacterial efficacy.

\section{EXPERIMENTAL}

Sodium bis(2-ethylhexyl) sulfosuccinate which is also called as Aerosol-OT (AOT), polyethylene glycol mono- $p$ isooctylphenyl ether (Triton X-100), Iso-octane and butanol were purchased from Merck Specialities Private Limited, Mumbai, India and the other chemicals used in the processes were of analytical grade.

Crude extract preparation: Fresh Aloe vera leaves were collected from the nearby garden and were washed twice in the distilled water. The gel and the outer green rind were separated and homogenized thoroughly in $10 \mathrm{mM}$ phosphate buffered saline of $\mathrm{pH} 7.4$ and it was incubated for $2 \mathrm{~h}$ at $4{ }^{\circ} \mathrm{C}$. The homogenate was centrifuged at $10,000 \mathrm{rpm}$ for $20 \mathrm{~min}$. The supernatant was filtered using Whatman paper No.1 and stored at $4{ }^{\circ} \mathrm{C}$ for further extraction and purification processes.

Ammonium sulphate precipitation: The crude extract obtained was saturated with $30 \%$ ammonium sulphate and left overnight at $4{ }^{\circ} \mathrm{C}$. Then it was centrifuged at $10000 \mathrm{rpm}$ for $20 \mathrm{~min}$ and the supernatant was again saturated with $65 \%$ ammonium sulphate and left overnight at $4{ }^{\circ} \mathrm{C}$. After that it was centrifuged at $10000 \mathrm{rpm}$ for $20 \mathrm{~min}$. The pellets obtained after centrifugation process was collected and dissolved in phosphate buffered saline.

Reverse micellar extraction: Forward extraction step was carried out by combining two surfactants, $150 \mathrm{mM}$ AOT and $15 \mathrm{mM}$ Triton $\mathrm{X}-100$ in $5 \mathrm{~mL}$ of iso-octane by injecting $1 \mathrm{~mL}$ of crude sample in $5 \mathrm{~mL}$ of $\mathrm{pH} 4$ buffer containing $30 \mathrm{mM}$ $\mathrm{NaCl}$ for $30 \mathrm{~min}$. Backward extraction step was carried out by adding $3 \mathrm{~mL}$ of pH 8 buffer containing $500 \mathrm{mM} \mathrm{KCl}$ and $5 \%$ $(\mathrm{w} / \mathrm{v})$ butanol to the $3 \mathrm{~mL}$ of micellar phase obtained from the forward step left for $30 \mathrm{~min}$. Then it was centrifuged at 3000 rpm for $5 \mathrm{~min}$ and the aqueous phase was collected and used for determining the protein content and the activity of the lectin. All the steps were carried out at room temperature.

Estimation of protein content: The protein concentration in the crude, in the supernatant obtained after ammonium sulphate precipitation process and in the aqueous phase obtained after reverse micellar extraction was estimated by Bradford method $^{29}$ using bovine serum albumin (BSA) as standard, at a range of $0-1000 \mu \mathrm{g} / \mathrm{mL}$. The respective blank solutions were used for sample analysis. All the readings for the estimation of protein content were taken in triplicate for all the processes and an average value was used for the estimation of extraction efficiency.

$$
\text { Extraction efficiency (\%) }
$$

$$
=\frac{\text { Protein content in the aqueous phase (backward) }}{\text { protein content in the crude }} \times 100
$$

Ion exchange chromatography: The samples obtained after the reverse micellar extraction process was dialyzed against deionized water for overnight and then the sample was subjected to cation exchange chromatography (CM-Sepharose column) in AKTAprime plus GE Healthcare system, which was pre-equilibrated at $24^{\circ} \mathrm{C}$ and $\mathrm{pH} 6.6$ using $10 \mathrm{mM}$ Tris$\mathrm{HCl}$ buffer as binding buffer and $20 \mathrm{mM} \mathrm{NaCl}$ solution as elution buffer at the same $\mathrm{pH}$ of 6.6. The sample flow rate was maintained at $2 \mathrm{~mL} / \mathrm{min}$ throughout the run of the column.

Molecular mass determination: SDS-PAGE electrophoresis for the fraction collected from the column was carried out using $12 \%$ separating and $5 \%$ stacking gel according to the Laemmli method ${ }^{30,31}$ and the gel was stained using Coomassie brilliant blue R-250 for detecting the molecular weight of the purified fraction.

Haemagglutination assay: To determine the haemagglutination activity, human red blood cells (RBCs) of $1 \%$ was suspended in $20 \mathrm{mM}$ phosphate buffered saline $\mathrm{pH} 7.2$ and a round-bottomed 96 well microtitre plate was used. $200 \mu \mathrm{L}$ of sample was added to the first column and to the remaining columns $100 \mu \mathrm{L}$ of phosphate buffered saline was added. 100 $\mu \mathrm{L}$ from the first column was transferred to the next well and it was mixed thoroughly, the same procedure was repeated till the last well and $100 \mu \mathrm{L}$ from the last well was discarded. 100 $\mu \mathrm{L}$ of the prepared RBC solution was added to the above wells. $100 \mu \mathrm{L}$ of phosphate buffered saline in $100 \mu \mathrm{L}$ of RBC solution was treated as negative control and similarly $100 \mu \mathrm{L}$ of trichloroacetic acid (TCA) with $100 \mu \mathrm{L}$ of RBC solution was treated as the positive control. The above plates were left at room temperature for $1 \mathrm{~h}$ and visualized under the microscope. The negative control appeared as dot in the round bottomed titer plates. Positive control formed a uniform reddish colour aggregate across the well ${ }^{9}$. This procedure was done for the crude and the fraction collected from the chromatography column. The haem-agglutination unit per gram (HU/g) was determined by the equation ${ }^{32}$.

$$
\frac{\mathrm{HU}}{\mathrm{g}}=\frac{\mathrm{Da} \times \mathrm{Db} \times \mathrm{S}}{\mathrm{V}}
$$

where, Da: Dilution factor of the first well, Db: Dilution factor of the last well till which haemagglutination occurs, S: Inverse of sample or initial crude concentration $(\mathrm{mL} / \mathrm{mg})$, V: Sample volume added $(\mathrm{mL})$.

in vitro Antibacterial activity: The fraction collected from the column was studied for the antibacterial activity by using agar well diffusion method utilizing different bacterial species namely Enterobacter aerogenes, Escherichia coli, Aeromonas hydrophila, Klebsiella pneumoniae, Salmonella typhi, Pseudomonas aeruginosa, Staphylococcus aureus and Bacillus cereus. Chloramphenicol was used as the positive control and 
phosphate buffered saline was used as the negative control. The inoculated plates were left for $24 \mathrm{~h}$ in the incubator at $37{ }^{\circ} \mathrm{C}$ for the growth of bacteria and after that the zone of inhibition was measured for assessing the antibacterial activity.

in vitro Antioxidant study: The fraction collected was subjected to antioxidant studies using reducing power assay in which potassium ferricyanide $(1 \% \mathrm{w} / \mathrm{v})$ was used. Varying concentration of sample was made to $1 \mathrm{~mL}$ with methanol, which was mixed with $2.5 \mathrm{~mL}$ of potassium ferricyanide and $2.5 \mathrm{~mL}$ of phosphate buffer $\mathrm{pH}$ 6.6. This was kept in hot water bath at $50{ }^{\circ} \mathrm{C}$ for $20 \mathrm{~min}$. Then $2.5 \mathrm{~mL}$ of this solution was mixed with $2.5 \mathrm{~mL} \mathrm{TCA}(10 \% \mathrm{w} / \mathrm{v})$ and $0.5 \mathrm{~mL}$ ferric chloride $(0.1 \% \mathrm{w} / \mathrm{v})$ and it was incubated for $10 \mathrm{~min}$. The Perl's Prussian blue colour was obtained due to the formation of iron(II)ferricyanide complex, which was measured as the absorbance value at $700 \mathrm{~nm}$.

\section{RESULTS AND DISCUSSION}

Initial protein content: The initial protein content was measured in the crude extract using Bradford assay ${ }^{29}$ and it was found that Aloe vera gel contains lesser protein content compared to its outer green rind, which was found to be 0.8 $\mathrm{mg} / \mathrm{mL}$ in Aloe vera gel and $2.312 \mathrm{in} \mathrm{mg} / \mathrm{mL}$ in Aloe vera leaf extracts. Hence Aloe vera outer rind was chosen for further extraction processes like ammonium sulphate precipitation and reverse micellar extraction leaving out the gel parts of the leaves.

\section{Reverse micellar extraction (RME)}

\section{Forward extraction}

Effect of pH: The extraction of lectin into the reverse micelles is mainly influenced by the $\mathrm{pI}$ (isoelectric point) of the lectin. The $\mathrm{pH}$ of the system varied from 4 to 10 . If the $\mathrm{pH}$ is less than pI, the lectin becomes more positively charged and gets attracted to the head-groups of AOT. The similar pattern was observed in this system also. At this $\mathrm{pH}$ only, proteins are transferred to the micelle phase because protein solubilization is enhanced by electrostatic interactions between surfactant head groups and protein molecules ${ }^{26}$. At $\mathrm{pH} 5$ only the maximum amount of protein was transferred to the micelle phase (Fig. 1a).
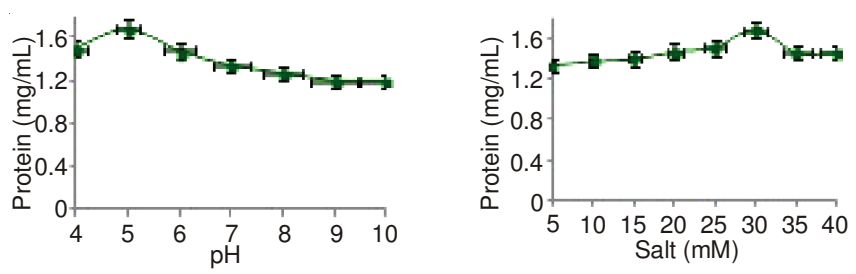

Fig. 1. Effect of $\mathrm{pH}$ and ionic strength in forward extraction

Effect of ionic strength ( $\mathrm{NaCl})$ : $\mathrm{The} \mathrm{NaCl}$ salt was used in the forward extraction process because this salt have a capability of forming the water structure and also have higher ionic strength, which reduces the interactions between the surfactants groups and the hydrophilic protein part and causes the formation of smaller micelles ${ }^{19}$. The $\mathrm{NaCl}$ concentration varied from 5-40 mM (Fig. 1b). The maximum protein content was observed in the micelle phase at $30 \mathrm{mM} \mathrm{NaCl}$ concentration.

\section{Effect of Surfactants concentration (AOT and Triton X-100)}

AOT: Increase in the AOT amount in the organic phase, increases the solubilization of proteins due to the increase in the reverse micelles size ${ }^{19}$. The low concentration of AOT is useful in minimizing the precipitation of the proteins at the interface and in this concentration proper transfer of the proteins from aqueous to organic phase does not take place ${ }^{28}$. At high concentration of AOT, the release of proteins from organic to aqueous phase in the backward extraction process also becomes difficult ${ }^{19}$. The AOT concentration varies from 50-300 $\mathrm{mM}$ and the maximum protein content was transferred from the aqueous to the micelle phase at $150 \mathrm{mM}$ concentration of AOT (Fig. 2a).
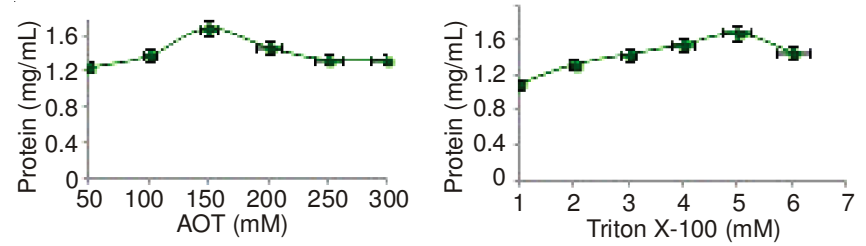

Fig. 2. Effect of surfactant concentration in forward extraction

Triton X-100: A nonionic surfactant Triton X-100 added reduces the inhibitory power of the AOT on the proteins due to the dilution of the surface charge density. Thus the Triton $\mathrm{X}-100$ added protects lectin from the action of AOT as there is a decrease in the electrostatic and hydrophobic interactions between the protein and the surfactants ${ }^{18}$. Triton X-100 concentration varied from 1-6 mM and it was found that maximum protein content was transferred to the micelle phase at $5 \mathrm{mM}$ Triton X-100 concentration (Fig. 2b).

Effect of solvents (iso-octane): Water solubilization in reverse micellar extraction was found to vary with the type of solvents used. The amount of water content (Wo) in the isooctane increases the usage of iso-octane in the reverse micellar extraction process. Increase in the solvents molecular volume increases Wo value. This may be due to the easy penetration of smaller molecular volume solvents into the surfactants hydrocarbon chains existing at the reverse micelles interfacial films. Because of this, surfactants packing parameter increases and in turn micelles diameter and water content decreases ${ }^{18}$.

\section{Backward extraction}

Effect of pH: The increase in yield and extraction efficiency $\%$ of the backward extraction process occurs at a $\mathrm{pH}$ greater than the $\mathrm{pI}$ of the lectin. At this $\mathrm{pH}$, the electrostatic interactions are altered by decreasing the repulsions of the surfactant head groups which leads to the formation of smaller reverse micelles, which in turn allows the release of protein from the micellar phase to the aqueous phase in the backward extraction $^{19}$. The $\mathrm{pH}$ of the aqueous phase varied from 4 to 10 . The maximum protein content was transferred from the micelle to the aqueous phase at pH 8 (Fig. 3a).

Effect of solvent concentration (butanol): In the backward extraction process, butanol was added to the organic phase in order to transfer the lectin to the aqueous phase from the reverse micelles. Interaction between the micelles and the solubilized proteins leads to the decrease in the backward 


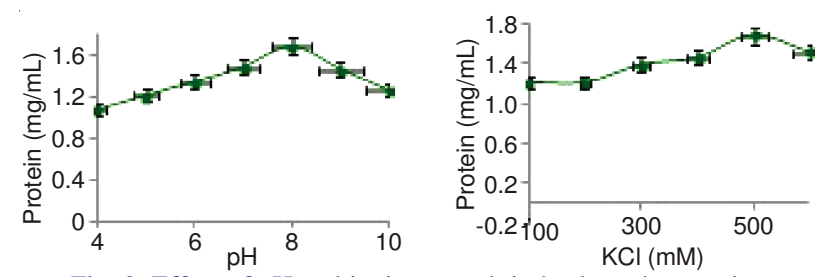

Fig. 3. Effect of $\mathrm{pH}$ and ionic strength in backward extraction

extractions. So the control in the micelle- micelle interactions plays a major role in the successful backward extractions of the lectin. Alcohols are treated as a good reverse micellar modifying agent because of the amphiphilic property of the alcohols, which also makes it a co-surfactant. Alcohols such as butanol reduce the micelle-micelle interactions, which in turn decreases the micellar interface resistance thereby improving the backward extraction ${ }^{18}$. Hence $5 \%(\mathrm{w} / \mathrm{v})$ butanol was used in the backward extraction.

Effect of KCl: Increase in salt concentration increases the backward extraction. Because increase in salt concentration decreases the size of the reverse micelles and the proteins accumulated inside the micelles are easily expelled out from the organic to the aqueous phase. This salt also has a capability of breaking the water structure. At high concentration of salt, the precipitation occurs at the interface of the two phases and the activity recovery was also decreased. This may be due to the denaturation of the proteins at higher ionic strength because the surface hydrophobicity of proteins increases at high salt concentration. The $\mathrm{KCl}$ concentration varied from 100-600 $\mathrm{mM}$ and it was found that the maximum protein content was transferred from the micelle phase to the aqueous phase at $500 \mathrm{mM}$ concentration of $\mathrm{KCl}$ (Fig. 3b)).

Comparison of two methods: The sample obtained after ammonium sulphate precipitation and reverse micellar extraction processes were compared and it was found that reverse micellar extraction showed highest extraction efficiency (yield) than the ammonium sulphate precipitation. The protein content in the crude extracts was estimated to be $2.312 \mathrm{mg} / \mathrm{mL}$ and sample obtained after ammonium sulphate precipitation and reverse micellar extraction was found to be 1.77 and 2.068 $\mathrm{mg} / \mathrm{mL}$, respectively.

Ion exchange chromatography: The sample obtained after dialysis was subjected to ion exchange chromatography, in which CM-sepharose column was used and it showed a single peak (Fig. 4) which indicates the purity of lectin extracted from crude using reverse micellar extraction. The fraction collected from the column was according to the chromatogram obtained, it was collected starting from 1-3.5 mL volume of the sample and the peak obtained showed a maximum of 350 $\mathrm{mAu}$ at $280 \mathrm{~nm}$.

SDS page analysis: The purified fraction from the chromatographic column obtained after reverse micellar extraction showed a single sharp band in SDS PAGE analysis (Fig. 5) with a molecular weight of $55 \mathrm{KDa}$ corresponding to the molecular markers, which confirmed that it was lectin isolated from the Aloe vera leaf extracts. Which is in agreement with earlier reports ${ }^{17}$.

Haemagglutination assay: The fraction of the sample collected from the column and subjected to haemagglutinating activity (Fig. 6). The results were positive and encouraging.

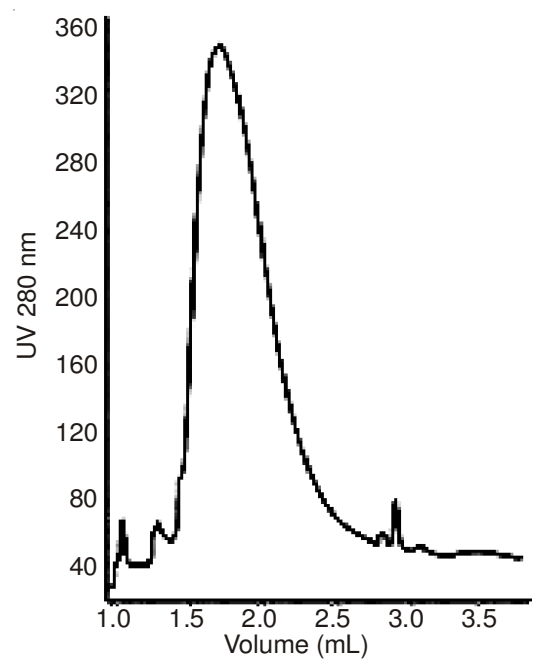

Fig. 4. Ion exchange chromatogram

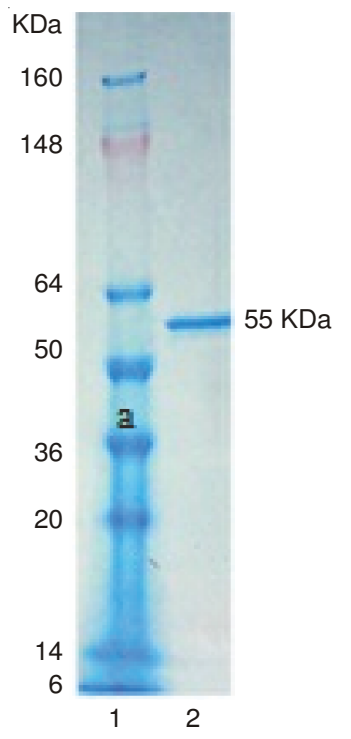

Fig. 5. SDS-PAGE analysis

a

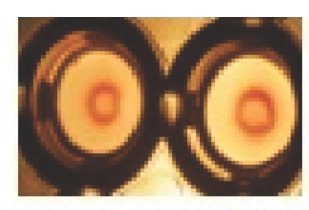

b

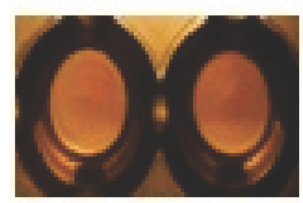

C

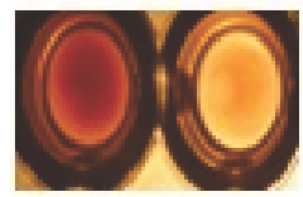

d

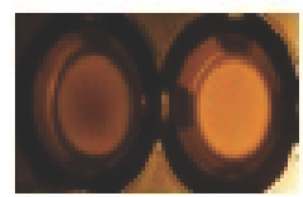

Fig. 6. Hemagglutination assay. a. negative control; b. positive control; c. crude and d. fraction collected 
The strength of the haemagglutination (unit per gram) was measured for the crude and the fraction collected from the column and it was tabulated in Table-1. The haemagglutination result clearly confirms the presence of lectin in the purified fraction $^{9-11}$.

\section{TABLE-1}

\section{HAEMAGGLUTINATION ASSAY}

\begin{tabular}{lcc}
\hline \multicolumn{1}{c}{ Sample } & $\mathrm{HU}(\mathrm{g})$ & Strength of the assay \\
\hline Crude & 30.28 & ++ \\
Sample obtained from IEX column & 43.52 & +++ \\
\hline
\end{tabular}

Antibacterial activity: The plates inoculated with Gramnegative bacteria alone showed zone of inhibition and values are presented in the graph (Fig. 7). In the other plates which were inoculated with Gram-positive bacteria, the control alone showed the zone of inhibition. This illustrates that the fraction collected does not inhibit the growth of the Gram-positive bacteria. Inhibits only the growth of the Gram-negative bacteria.

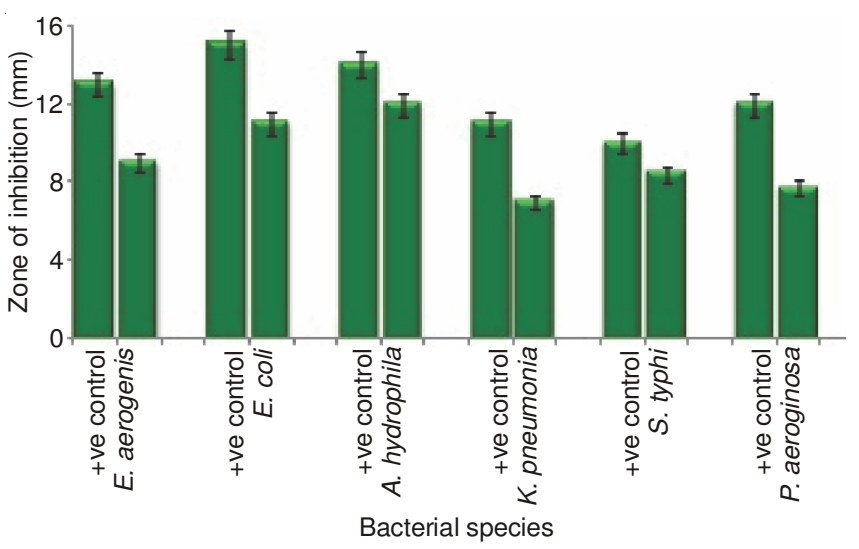

Fig. 7. Antibacterial activity of Aloe vera leaf extracts

Antioxidant activity: In this reducing power assay, it is noticed that the antioxidants present in the sample would have reduced $\mathrm{Fe}^{3+}$ of the ferric chloride to $\mathrm{Fe}^{2+}$, resulting in the colour change to occur, that is the formation of the prussian blue colour. The change in colour can be detected by measuring the absorbance at $700 \mathrm{~nm}$. The increased absorbance value indicates the increase in reducing ability (Fig. 8). This reducing ability confirms the presence of the antioxidants, which in turn converts the free radicals to the stable products and it also prevents the chain reactions which initiates the formation of free radicals.

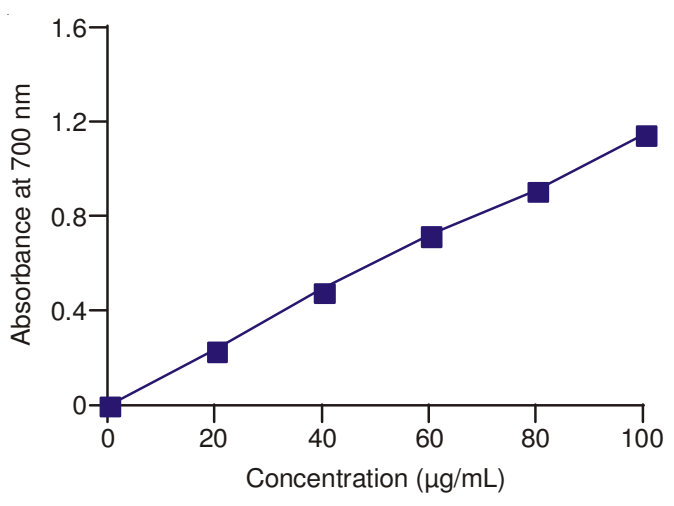

Fig. 8. Antioxidant activity of Aloe vera leaf extracts

\section{Conclusion}

In the present study, it is concluded that extraction of lectins from crude extracts of Aloe vera leaves using reverse micellar extraction process is found to be useful due to its high extraction efficiency and yield as compared to the ammonium sulphate precipitation method. This method also overcomes the draw backs existing in other traditional methods. The purified lectin obtain was also found to exhibit haemagglutinating, antibacterial and antioxidant activity.

\section{REFERENCES}

1. T. Reynolds and A.C. Dweck, J. Ethnopharmacol., 68, 3 (1999).

2. M.S. Moghaddasi and S.K. Verma, Int. J. Biol. Med. Res., 2, 466 (2011).

3. A. Surjushe, R. Vasani and D.G. Saple, Indian J. Dermatol., 53, 163 (2008).

4. S. Singh, P.K. Sharma, N. Kumar and R. Dudhe, Int. J. Pharm. Sci., 2, 1224 (2010).

5. M.D. Boudreau and F.A. Beland, J. Environ. Sci. Health C, 24, 103 (2006).

6. M. Bhattacharya, S. Malik and A. Singh, J. Pharm. Res., 4, 4507 (2011).

7. W.D. Winters, Phytother. Res., 7, S23 (1993).

8. Y.F. Hou, Y.B. Hou, Y.Y. Liu, Q. Guang and J.C. Li, J. Biomed. Biotechnol., Article ID 217342 (2010).

9. J. Shi, S.J. Xue, Y. Kakuda, S. Ilic and D. Kim, Process Biochem., 42, 1436 (2007).

10. N.N. Nagre, V.B. Chachadi, P.M. Sundaram, R.S. Naik, R. Pujari, P. Shastry, B.M. Swamy and S.R. Inamdar, Glycoconj. J., 27, 375 (2010).

11. A. Sharma, T.B. Ng, J.H. Wong and P. Lin, J. Biomed. Biotechnol., Article ID 929568 (2009).

12. E.C. van Asbeck, A.I.M. Hoepelman, J. Scharringa, B.L. Herpers and J. Verhoef, BMC Microbiol., 8, 229 (2008).

13. Y. Luo, X. Xu, J. Liu, J. Li, Y. Sun, Z. Liu, J. Liu, E.V. Damme, J. Balzarini and J. Bao, J. Biochem. Mol. Biol., 40, 358 (2007).

14. C. Bies, C.-M. Lehr and J.F. Woodley, Adv. Drug Deliv. Rev., 56, 425 (2004).

15. J. Li, H. Wu, J. Hong, X. Xu, H. Yang, B. Wu, Y. Wang, J. Zhu, R. Lai, X. Jiang, D. Lin, M.C. Prescott and H.H. Rees, PLoS ONE, 3, e2381 (2008).

16. L.G. Barrientos and A.M. Gronenborn, Mini Rev. Med. Chem., 5, 21 (2005).

17. M. Kaur, J. Singh and S.S. Kamboj, J. Pharm. Res., 4, 2441 (2011).

18. A.B. Hemavathi, H.U. Hebbar and K.S.M.S. Raghavarao, Separ. Purif. Tech., 71, 263 (2010).

19. C.O. Nascimento, R.M.P.B. Costa, R.M.S. Araújo, M.E.C. Chaves, L.C.B.B. Coelho, P.M.G. Paiva, J.A. Teixeira, M.T.S. Correia and M.G. Carneiro-da-Cunha, Process Biochem., 43, 779 (2008).

20. C.O. Nascimento, L.C.B.B. Coelho, M.T.S. Correia and M.G. Carneiroda-Cunha, Biotechnol. Lett., 24, 905 (2002).

21. H. Umesh Hebbar, B. Sumana and K.S.M.S. Raghavarao, Bioresour. Technol., 99, 4896 (2008).

22. A.B. Hemavathi, U.H. Hebbar and K.S.M.S. Raghavarao, J. Chem. Technol. Biotechnol., 82, 985 (2007).

23. C. Jolivalt, M. Minier and P. Renon, Biotechnol. Prog., 9, 456 (1993).

24. M. Dekker, R. Hilhorst and C. Laane, Chem. Eng. Sci., 178, 217 (1989).

25. K.E. Cöklen and T.A. Hatton, Biotechnol. Prog., 1, 69 (1985).

26. M.J. Pires, M.R. Aires-Barros and J.M.S. Cabral, Biotechnol. Prog., 12, 290 (1996).

27. Y.- Yu, Y. Chu and J.-Y. Ji, J. Colloid Interf. Sci., 267, 60 (2003)

28. J.R.S. Alves, L.P. Fonseca, M.T. Ramalho and J.M.S. Cabral, Biochem. Eng. J., 15, 81 (2003).

29. M.M. Bradford, Anal. Biochem., 72, 248 (1976).

30. B.D. Hames and D. Rickwood, Gel Electrophoresis of Proteins-A Practical Approach, edn 2, Oxford University Press, New York (1990).

31. U.K. Laemmli and M. Favre, J. Mol. Biol., 80, 575 (1973).

32. I.E. Liener and E.G. Hill, J. Nutr., 49, 609 (1953). 